\title{
CMV meningitis associated with dimethyl fumarate therapy-induced lymphopenia in a multiple sclerosis patient
}

\author{
Ann-Kathrin Kogel ${ }^{1}\left(\mathbb{D} \cdot\right.$ Ralf Gold $^{1} \cdot$ Ruth Schneider $^{1}$
}

Received: 2 April 2021 / Revised: 9 June 2021 / Accepted: 11 June 2021 / Published online: 27 June 2021

(c) The Author(s) 2021

$\begin{array}{ll}\text { Abbreviations } \\ \text { ALC } & \text { Absolute lymphocyte counts } \\ \text { CMV } & \text { Cytomegalovirus } \\ \text { CSF } & \text { Cerebrospinal fluid } \\ \text { DMF } & \text { Dimethyl fumarate } \\ \text { HIV } & \text { Human immunodeficiency virus } \\ \text { PCR } & \text { Polymerase chain reaction } \\ \text { RRMS } & \text { Relapsing-remitting multiple sclerosis } \\ \text { TOF } & \text { Time-of-flight } \\ \text { UTI } & \text { Urinary tract infection } \\ \text { WBC } & \text { White blood cells }\end{array}$

Dear Sirs,

A 55-year-old Caucasian man with relapsing-remitting multiple sclerosis (RRMS) presented to hospital with headache, neck pain, nausea and chills. Symptoms started 3 hours prior to his presentation. Clinical examination showed meningism. MS was diagnosed in 2018 and was currently treated with dimethyl fumarate (DMF) (480 mg/day) for the last 9 months (4/20-1/21). Recommended white blood cell controls had not been realized in the last 6 months by the outpatient physicians. Previous MS therapy was $300 \mathrm{mg}$ ocrelizumab in March 2018, after one infusion this therapy was stopped on patients' request. His medical history included type 2 diabetes mellitus (HbA1c 6.4\%; normal value: 4.8-6.0), hypertension and coronary artery disease.

Upon admission, blood count showed a normal white cell count $(9480 / \mu \mathrm{l})$ but marked lymphopenia $(240 / \mu \mathrm{l})$. C-reactive protein was $18.40 \mathrm{mg} / \mathrm{l}$ (normal value $<5 \mathrm{mg} / \mathrm{l}$ ), procalcitonin was $4.68 \mathrm{ng} / \mathrm{ml}$ (normal value $0.5 \mathrm{ng} / \mathrm{ml}$ ). U-Status showed a urinary tract infection (UTI), blood

Ann-Kathrin Kogel

ann-kathrin.kogel@rub.de

1 Department of Neurology, St. Josef-Hospital, RuhrUniversity Bochum, Gudrunstr. 56, 44791 Bochum, Germany cultures detected E.coli in 4/4 cultures. Lumbar puncture revealed clear cerebrospinal fluid (CSF), investigations presented 3 white blood cells (WBC)/ $\mu$ with mildly raised lactate $(29 \mathrm{mg} / \mathrm{dl}$; normal value $10-22 \mathrm{mg} / \mathrm{dl})$, normal protein (25 mg/dl; normal value $15-45 \mathrm{mg} / \mathrm{dl}$ ) and glucose levels (CSF $115 \mathrm{mg} / \mathrm{dl}$, serum $246 \mathrm{mg} / \mathrm{dl}$ ). Multiplex-polymerase chain reaction (PCR) of the CSF was positive for cytomegalovirus (CMV), further CMV-PCR amplification detected 46000copies/ml. CMV serology was positive for anti-CMV IgG $(68.00 \mathrm{U} / \mathrm{ml}$; normal value $<0,5 \mathrm{U} / \mathrm{ml})$, while anti-CMV IgM and CMV-PCR in serum were negative. Brain MRI did not show any signs of encephalitis or vasculitis in time-offlight (TOF) - angiography. Serological testing for hepatitis $\mathrm{B}$ and $\mathrm{C}$ and human immunodeficiency virus (HIV) was negative.

Given the clinical picture the diagnosis was CMV meningitis and urosepsis. DMF therapy was immediately stopped. The patient was started on intravenous ganciclovir $600 \mathrm{mg}$ two times a day for 16 days. Lumbar puncture was performed on day 4, 11 and 15 and showed a significant decrease of CMV-DNA count (day 4 18,600 copies/ml, day 112000 copies/ml, day 15 no CMV-DNA detectable). Urosepsis was simultaneously treated with ceftriaxone and the patient gradually improved.

Worldwide CMV seroprevalence is estimated around $40-100 \%$ in the general population. In immune-competent hosts primary infection is usually asymptomatic or unspecific, e.g., fever or respiratory symptoms [1]. Persons with immune deficiency may suffer a severe disease course with pneumonia, meningitis or encephalitis $[1,2]$. In the context of MS therapies, CMV infections were described during natalizumab [3] and alemtuzumab [4] treatment.

DMF is an oral disease-modifying therapy with potential immunomodulatory effects approved for patients with RRMS. In the phase 2b/3/long-term studies absolute lymphocyte count (ALC) decreased by $30 \%$ during the first year of DMF treatment followed by stabilization [5]. Regarding immune cell subsets, the relative frequencies of circulating memory T- and B-cell populations declined and naive cells 
increased. CD4 and CD8 T-lymphocyte counts closely correlated with ALC [6]. Increased incidence of serious infections was not observed in the long-term extension studies $[5,7]$.

To our knowledge, CMV meningitis under DMF treatment has not been reported yet. In view of positive CMVspecific PCR in CSF and IgG but not IgM antibody response, a reinfection or reactivation has to be assumed. The setting of immunosuppression and E.coli associated UTI with CMV reactivation was further described in the context of kidney transplants [8]. Other potential risk factors than DMF could be previous ocrelizumab therapy and diabetes mellitus. Since ocrelizumab was stopped almost three years prior and $\mathrm{HbA} 1 \mathrm{c}$ was $6,4 \%$, we considered these factors less likely to be causative, but cannot completely exclude it. Reduced immune response with moderate WBC-elevation and lymphopenia even in the context of systemic infection may explain absence of pleocytosis despite presence of CMVmeningitis. In summary, we aim to point out that lymphopenia is an important side effect of DMF treatment which needs to be watched closely especially in the 1st year after starting treatment.

Author contributions AK: acquisition of data, analysis and interpretation of data, drafting of the manuscript. RG: acquisition of data, analysis and interpretation of data, revising the manuscript. RS: acquisition of data, analysis and interpretation of data, revising the manuscript. All authors read and approved the manuscript.

Funding Open Access funding enabled and organized by Projekt DEAL. Not applicable.

Availability of data and materials Not applicable.

Code availability Not applicable.

\section{Declarations}

Conflicts of interest $\mathrm{AK}$ has nothing to report. RG received honoraria for lecturing and advisory boards from Biogen. His institution receives grant support for IIT studies. RS has received consulting and speakers honoraria from Biogen Idec GmBH and Roche Pharma AG \& has received research scientific grant support from Novartis Pharma.

Ethics approval and consent to participate Not applicable.
Consent for publication Written informed consent for publication was obtained.

Open Access This article is licensed under a Creative Commons Attribution 4.0 International License, which permits use, sharing, adaptation, distribution and reproduction in any medium or format, as long as you give appropriate credit to the original author(s) and the source, provide a link to the Creative Commons licence, and indicate if changes were made. The images or other third party material in this article are included in the article's Creative Commons licence, unless indicated otherwise in a credit line to the material. If material is not included in the article's Creative Commons licence and your intended use is not permitted by statutory regulation or exceeds the permitted use, you will need to obtain permission directly from the copyright holder. To view a copy of this licence, visit http://creativecommons.org/licenses/by/4.0/.

\section{References}

1. Micallef S, Galea R (2018) CMV encephalitis in an immunecompetent patient. BMJ Case Rep. https://doi.org/10.1136/ bcr-2018-224740

2. Ross SA, Novak Z, Pati S, Boppana SB (2011) Diagnosis of cytomegalovirus infections. Infect Disord Drug Targets 11(5):466-474

3. Lima M, Farias LA, da Ponte MF, Furdato LE (2019) Self-limited cytomegalovirus infection during natalizumab treatment for multiple sclerosis. EJCRIM. https://doi.org/10.12890/2019_001046

4. Clerico M, De Mercanti S, Artusi CA, Durelli L, Naismith RT (2017) Active CMV infection in two patients with multiple sclerosis treated with alemtuzumab. Mult Scler 23(6):874-876. https:// doi.org/10.1177/1352458516688350 (Epub 2017 Feb 1)

5. Fox RJ, Chan A, Gold R, Phillips JT, Selmaj K, Chang I, Novas M, Rana J, Marantz JL (2016) Characterizing absolute lymphocyte count profiles in dimethyl fumarate-treated patients with MS Patient management considerations. Neurol Clin Pract 6:220-229

6. Mehta D, Miller C, Arnold DL et al (2019) Effect of dimethyl fumarate on lymphocytes in RRMS: implications for clinical practice. Neurology 92:e1724-e1738. https://doi.org/10.1212/WNL. 0000000000007262 ((Published Online before print March 27, 2019))

7. Gold R, Giovannoni G, Phillips J, Bar-Or A, Fox R, Mokliatchouk O, Parks B, Miller C, Kapadia S (2020) FC02.05-safety and efficacy in patients treated with dimethyl fumarate and followed for 13 years: final results of ENDORSE. MSVirtual2020. Held online 11-13.09.2020

8. Bodro M, Sanclemente G, Lipperheide I, Allali M, Marco F, Bosch J, Cofan F, Ricart MJ, Esforzado N, Oppenheimer F, Moreno A, Cervera C (2015) Impact of urinary tract infections on short-term kidney graft outcome. Clin Microbiol Infect 21(12):1104.e1-8. https://doi.org/10.1016/j.cmi.2015.07.019 (Epub 2015 Jul 31) 